\title{
К ВОПРОСУ О СЕМЕЙНОМ ПАРТНЕРСТВЕ
}

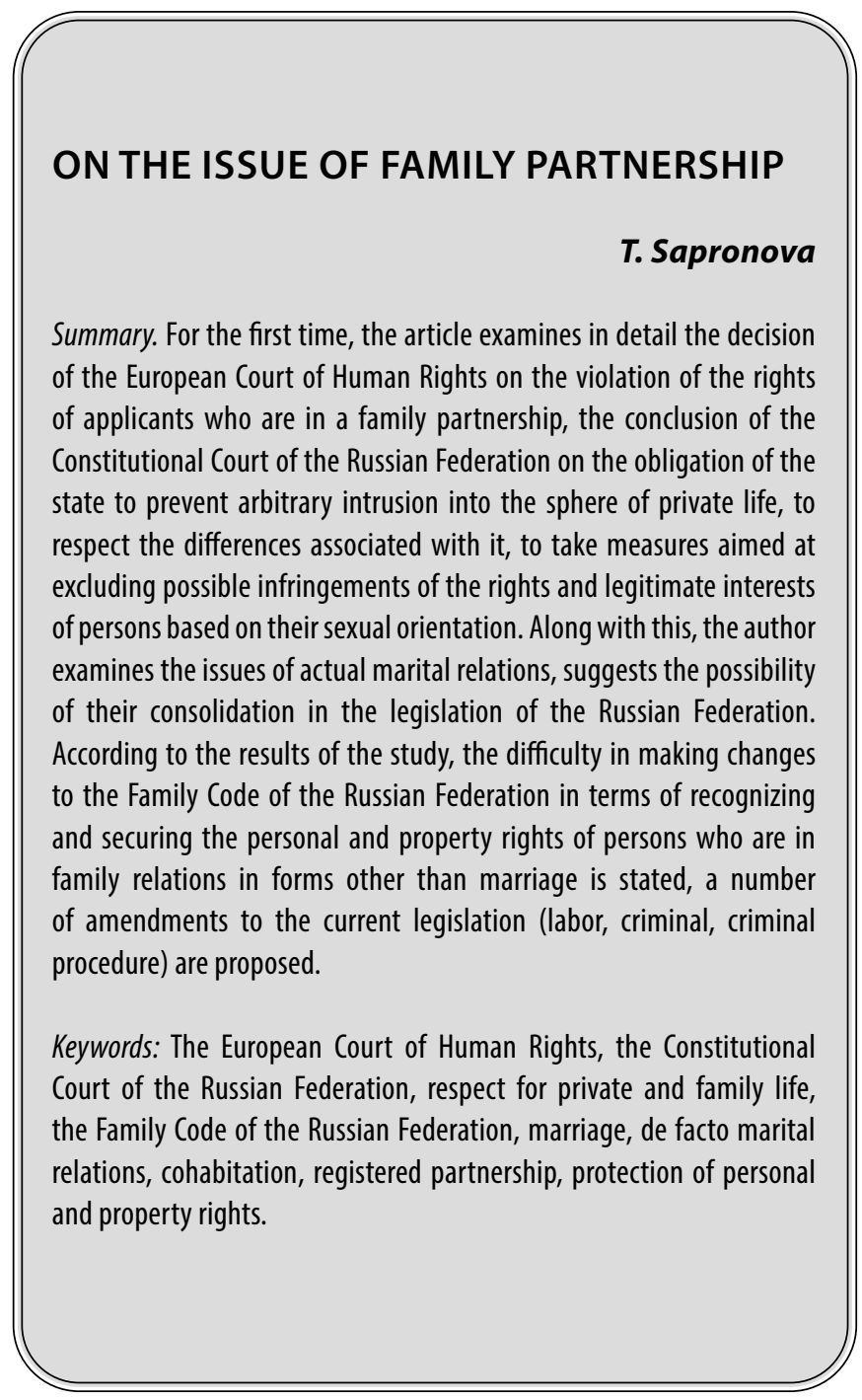

$\Pi$ остановлением от 13.07.2021[1] Европейский суд по правам человека (далее - ЕСПЧ) признал нарушением Российской Федерацией статьи восьмой Европейской конвенции о правах человека, в связи с отказом трем однополым парам из России заключить брак. По мнению ЕСПЧ, в данной, конкретной ситуации, имеет место нарушение права граждан Российской Федерации на уважение частной и семейной жизни.

По итогам обсуждения данного постановления политическая элита страны поспешила обвинить ЕСПЧ В юридической безграмотности, заявив о незнании им не только основ национального (российского) законодательства, но и самой Европейской конвенции о правах человека, в которой отсутствует прямое указание на необходимость признания однополых браков.

\author{
Сапронова Тамара Петровна \\ К.ю.н., дочент, ФГБОУ ВО «Тверской \\ государственный университет», г. Тверь \\ dgoki@mail.ru
}

Аннотация. В статье впервые детально рассматривается постановление Европейского суда по правам человека 0 нарушении прав заявителей, состоящих в семейном партнерстве, заключение Конституционного Суда Российской Федерации об обязанности со стороны государства не допускать произвольного вторжения в сферу частной жизни, уважать связанные с нею различия, принимать меры, направленные на исключение возможных ущемлений прав и законных интересов лиц по мотиву их сексуальной ориентации. Наряду с этим автором исследуются вопросы фактических брачных отношений, предлагается возможность их закрепления в законодательстве Российской Федерации. По результатам проведенного исследования констатируется трудность на пути внесения изменений в Семейный кодекс Российской Федерации в части признания и закрепления личных и имущественных прав лиц, находящихся в семейных отношениях в формах, отличных от брака, предлагается ряд поправок в действующее законодательство (трудовое, уголовное, уголовно-процессуальное).

Ключевые слова: Европейский суд по правам человека, Конституционный Суд Российской Федерации, уважение частной и семейной жизни, Семейный кодекс Российской Федерации, брак, фактические брачные отношения, сожительство, регистрируемое партнерство, защита личных и имущественных прав.

Например, председатель Комитета Совета Федерации по конституционному законодательству и государственному строительству Андрей Клишас прямо заявил, что перечитает Европейскую конвенцию о правах человека, чтобы найти «...там что-либо о необходимости признания однополых пар в том или ином качестве со стороны государства...» [2].

Возможно предположить, что основаниями для такого рода реакции послужили, в первую очередь, изменения, внесенные в Конституцию Российской Федерации, а также в Семейный Кодекс Российской Федерации в 2020-2021 годах.

Согласно им, брак в России рассматривается исключительно как союз мужчины и женщины. При этом 
запрещено исполнение на территории Российской Федерации решений межгосударственных органов, принятых на основе положений международных договоров, но противоречащих Конституции Российской Федерации, а также основам правопорядка и нравственности.

Однако если обратиться непосредственно к самому тексту документа ЕСПЧ, то можно сделать вывод, что содержащиеся в нем утверждения никак не противоречат национальному законодательству России, и уж тем более, не дискриминируют его.

Так, в постановлении ЕСПЧ не содержится призыв легализовать однополые браки в Российской Федерации.

В нем содержится призыв к Российской Федерации признать статус заявителей, состоящих в парах, в форме, отличной от брака.

По мнению ЕСПч, такой выход из ситуации, во-первых не будет находиться в противоречии с преобладающим в России «традиционным пониманием брака», а во вторых, предоставит юридическую основу для защиты отношений заявителей как однополых пар, поскольку «государство - ответчик» выступает только против однополых браков, но не против иных форм их юридического признания, которые могут существовать» [3] (например, гражданское партнерство, гражданский союз или гражданский договор солидарности).

Иными словами, российским властям, имеющим обязательства по исполнению положений Европейской конвенции о правах человека, предоставлена возможность обосновать, почему применительно к России непризнание однополых союзов не должно считаться нарушением прав однополых пар; почему в какой-то отличной от брака форме нельзя признать де-факто существующие в России однополые союзы, в которых люди находятся в семейных отношениях, (а семейные отношения - это не только брачные); почему эти самые семейные отношения однополых пар лишены в России какого бы то ни было признания со стороны государства, а значит и защиты (в части возможности не свидетельствовать против себя лично, членов семьи и близких родственников, от дискриминации при устройстве на работу, проблем материального и личного характера в сфере наследственного права, пенсионного обеспечения и налогообложения).

В этой связи необходимо отметить, что изложенная позиция ЕСПЧ никак не противоречит позиции Конституционного Суда Российской Федерации по указанному вопросу.
Согласно ему, государство не обязано создавать условия для пропаганды, поддержки и признания союзов лиц одного пола, однако поправка в Конституцию России о браке как союзе мужчины и женщины «...не означает, что предлагаемое положение <...> снимает с государства конституционные обязанности не допускать произвольного вторжения в сферу частной жизни, уважать связанные с нею различия, принимать меры, направленные на исключение возможных ущемлений прав и законных интересов лиц по мотиву их сексуальной ориентации...» [4].

При этом следует обратить внимание и на еще один очень важный момент состоявшегося решения ЕСПЧ: содержащиеся в нем выводы могут иметь вполне реальный социальный запрос со стороны разнополых пар, совместно проживающих в России, но не желающих, по тем или иным причинам, связывать себя узами брака.

В подтверждение данного вывода могут свидетельствовать и результаты опросов ВЦИОМ, согласно которым $81 \%$ россиян не считают незарегистрированный брак чем-то предосудительным, а 60\% уверены, что главный мотив для вступления в брак - рождение детей[5].

Так уж сложилось, что россияне, особенно молодого возраста, уже не считают штамп в паспорте необходимым условием для создания полноценной семьи. При этом само по себе «сожительство», с точки зрения закона, не порождает каких-либо юридических последствий, что ставит членов подобного союза в весьма уязвимое положение, особенно в случае появления в данном союзе детей.

Представляется, что с учетом именно последнего обстоятельства в 2015, 2018 годах на рассмотрение Государственной Думы Российской Федерации и вносились поправки в Семейный кодекс Российской Федерации, согласно которым мужчина и женщина, прожившие вместе более пяти лет, либо прожившие в течение двух лет при наличии общего ребенка (детей), признавались мужем и женой, если их брак официально не был зарегистрирован. Одновременно на имущество, нажитое в период совместного проживания, предлагалось распространить «законный режим имущества супругов», в соответствии с которым все, нажитое в период сожительства, признавалось совместной собственностью.

Данные поправки Государственной Думой Российской Федерации были отклонены.

Однако такое последовательное отложение решения вопроса на законодательном уровне не свидетельствует о его закрытии на уровне бытовом. 
Более того, вопросы легализации личных и имущественных прав фактических супругов, находящихся в разнополых или однополых союзах, диктуются временем и толерантным отношением к любой из вышеназванных форм партнерства в постоянно изменяющемся мире.

Подтверждением изложенному могут служить и ставшие достаточно распространенными в последнее время как в обществе, так и в научной литературе теории, основанные на плюралистической модели брака, согласно которым брак как союз одного мужчины и одной женщины изжил себя и не соответствует потребностям современного общества.

Некоторые авторы таких теории высказывают предположения о том, что в будущем лица, вступающие в брак, получат право с помощью договора выработать такую модель брака, которая будет для них наиболее приемлема, а государство лишь будет регистрировать их выбор[6].

В настоящее время в качестве новых видов супружеских союзов в зарубежных странах все чаще рассматриваются регистрируемое сожительство, либо регистрируемое партнерство. Названий много, но все указанные формы сожительства основаны на так называемом партнерстве - союзе двух равноправных и независимых субъектов как разного, так и одного пола, который не считается браком и регулируется специальным законодательством. Не лишним будет подчеркнуть важность юридического признания подобного рода семейного союза, поскольку в его рамках могут быть решены многие правовые проблемы партнеров.

Например, для гетеросексуальных пар возможность заключения партнерства, а не брака, может быть более привлекательной с точки зрения того, что дети, рожденные в партнерстве, не считаются автоматически детьми партнера-мужчины. Вместе с тем, если мужчина признает ребенка своим, то такое партнерство уже практически не будет отличаться от брака.
При этом никто не оспаривает тот факт, что принципиальное решение вопросов, связанных с семейным партнерством, потребует от государства и общества затрат как материального, так и нематериального характера, включая принятие соответствующего закона и последующее внесение изменений в действующее законодательство.

Но основное количество возможных вопросов можно будет снять уже на пути приравнивания статуса регистрированных партнеров к статусу супругов.

В частности, регистрированных партнеров следует отнести к «членам семьи и близких родственников», определяемым пунктом 4 статьи 5 действующего Уголовно-процессуального кодекса Российской Федерации.

Таким образом, на партнера автоматически распространится действие ст. 51 Конституции Российской Федерации, освобождающей от ответственности за отказ от дачи показаний против себя самого, членов семьи и близких родственников.

Необходимо внести изменения в ст. 136 Уголовного кодекса Российской Федерации, дополнив ее формулировкой о запрете дискриминации в зависимости от принадлежности к каким-либо сексуальным меньшинствам. Аналогичные изменения должны найти свое отражение и в статьях 2 и 64 Кодекса законов о труде Российской Федерации.

В семейное законодательство необходимо внести запрет на вступление в брак лица, находящегося в регистрированном партнерстве (соответствующая формулировка должна содержаться в тексте статей 14, 27 Семейного Кодекса Российской Федерации).

Также в Семейном кодексе Российской Федерации необходимо предусмотреть возможность изменения регистрированного партнерства на брак для тех пар, которые соответствуют требованиям действующего семейного законодательства.

\section{ЛИТЕРАТУРА}

1. Постановление ЕСПЧ по делу “Федотова и другие против России” (Fedotova and Others v. Russia, жалобы NN40792/10 и др.) 0 т 13 июля 2021 г. https:// european-court-help.ru/espch-rekomendoval-uzakonit-odnopolye-braki-v-rossii-no-ogovorilsja-chto-s-uchetom-tradicij-jeto-budet-na-usmotrenie-stranydelo-fedotova-i-drugie-protiv-rossii-fedotova-and-others-v-russia-40792-10/

2. [Электронный ресурс]https://news.mail.ru/society/47108500/

3. Постановление ЕСПЧ по делу “Федотова и другие против России” (Fedotova and Others v. Russia, жалобы NN40792/10 и др.) 0 о 13 июля 2021 г. https:// european-court-help.ru/espch-rekomendoval-uzakonit-odnopolye-braki-v-rossii-no-ogovorilsja-chto-s-uchetom-tradicij-jeto-budet-na-usmotrenie-stranydelo-fedotova-i-drugie-protiv-rossii-fedotova-and-others-v-russia-40792-10/ 
4. Заключение Конституционного Суда Российской Федерации от 16.03.2020 N1-3 «0 соответствии положениям глав 1, 2 и 9 Конституции Российской Федерации не вступивших в силу положений Закона Российской Федерации о поправке к Конституции Российской Федерации «0 совершенствовании регулирования отдельных вопросов организации и функционирования публичной власти», а также о соответствии Конституции Российской Федерации порядка вступления в силу статьи 1 данного Закона в связи с запросом Президента Российской Федерации». https://legalacts.ru/sud/zakliucheniekonstitutsionnogo-suda-rf-ot-16032020-n-1-z/

5. [Электронный ресурc] https://news.myseldon.com/ru/news/index/182098354

6. Антакольская М.В. Семейное право: Учебник. 3-е изд., перераб. и доп. М.: Норма: ИНФРА-М. 2010. С. 124.

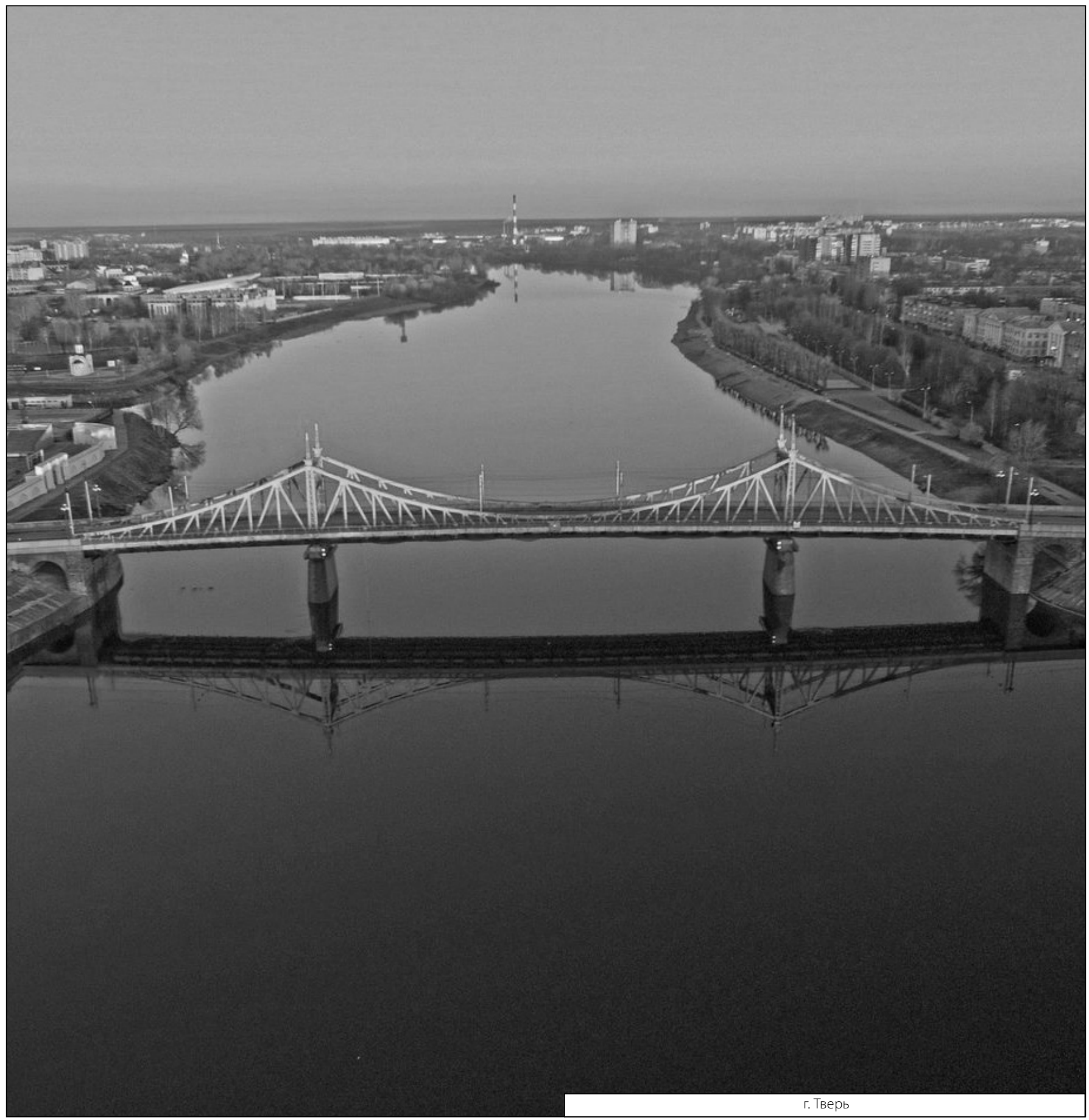

